\title{
Comparative Study of Biogas Generation Using Locally Constructed Bioreactor
}

\author{
Uchendu, D.O., Mbonu, F. O., Ukoha, P. U., Omiyi, C. E. \\ Department of Science Laboratory Technology, Akanu Ibiam Federal Polytechnic, Unwana, Afikpo, Ebonyi State, Nigeria
}

\begin{abstract}
This research work is focused on the construction of bioreactor for the production of biogas. This is due to the fact that Nigeria is facing energy problem. Biogas generation is an alternative area of research work and an alternative method for waste management. In this research work, two bioreactors were constructed using locally sourced materials and feed them with substrates, they are cow dung and kitchen waste in the ratio 1:2 (i.e. substrate to water) to form slurry. The slurry was transferred into the bioreactors for fermentation to generate biogas. The parameters such as temperature within and outside the bioreactors were observed and recorded weekly, the cumulative volume of biogas generated by each bioreactor were observed and recorded daily. The biogas generated was analyzed using gas chromatography. the result revealed that the average daily temperature in the bioreactors and ambient per day for the first week, for kitchen waste and cow dung and ambient were $32.224^{0} \mathrm{C}, 32.212^{\circ} \mathrm{C}, 28.789^{\circ} \mathrm{C}$, second week, $32.76^{\circ} \mathrm{C}, 32.072^{\circ} \mathrm{C}$, $28.441^{\circ} \mathrm{C}$, the third week, $30.882^{\circ} \mathrm{C}, 31.036^{\circ} \mathrm{C}$ and $28.612^{\circ} \mathrm{C}$ and the fourth week, $30.095^{\circ} \mathrm{C}, 30.509^{\circ} \mathrm{C}$ and $28,744^{\circ} \mathrm{C}$ respectively. It was observed that the biogas analysis using gas chromatography showed that kitchen waste had the gas component as follows $\mathrm{CH}_{4}, \mathrm{NH}_{3}, \mathrm{CO}, \mathrm{H}_{2} \mathrm{~S}$ and $\mathrm{CO}_{2}, 70.29 \%, 0.58 \%, 1.62 \%, 0.75 \%$ and $26.76 \%$ whereas cow dung had $68.26 \%, 0.49 \%, 1.18 \%, 0.15 \%$ and $29.92 \%$ respectively. Daily cumulative volume of biogas generated indicates that the first twenty hours had no gas generated, due to the fact that the organisms are trying to adapt to the new environment. The total volume of biogas generated from cow dung and kitchen waste after twenty eight days of fermentation were $167.4 \mathrm{~cm}^{3}$ and $192.7 \mathrm{~cm}^{3}$ respectively. It was revealed from this research work that the two subtracts used in this locally constructed bioreactors are excellent materials for biogas generation.
\end{abstract}

\section{INTRODUCTION}

$\mathrm{D}$ eveloped countries have a major advantage over the control of pollutions as they provide highly advanced methodologies in controlling various types of pollutants (1),

Biogas refers to a gas made from anaerobic digestion of substrates for biogas generation, kitchen waste and cow dungs are organic materials having the high calorific value and nutritive value to microbes, that's why efficiency of methane production can be increases. Inadequate management of wastes live uncontrolled dumping bears adverse consequences. It not only leads to polluting surfaces and groundwater through leachate and further promotes the breeding of flies, mosquitoes, rates and other disease bearing vectors (2). Kitchen waste and cow dung comprises high fraction of organic matter which causes environmental and health risks, have the need for a strong appropriate management system. In most cities in Nigeria, waste is disposed off as landfills or discarded which causes health hazard (2).

Historical evidence indicates that the anaerobic digestion process is one of the oldest technologies (3). The industrialization of anaerobic digestion began in 1859 with the digestion plant in Bambay, by 1895; biogas was recovered from a sewage treatment facility and used to fuel street lamps in Exeter, England (3). In Nigeria, research into biogas technology and its practical application in on-going, though, has not really received the deserves attention. The Sokoto Energy Research Centre Usman Danfodio University, Sokoto has carried out a number of pilot projects on construction of house hold size digesters.

In addition to this, the centre has constructed biogas digester plants of $20 \mathrm{~cm}^{3}$ capacities at three locations in Nigeria (4).

\section{METHODOLOGY}

The materials for the construction of the bioreactors are plastic drum, PVC pipe 4 inches, PVC accessories, gas hose, gas burner, $3 / 4$ air valve, $1 / 2$ air valve, thermometer, pressure gauge, gas storage device.

\section{CONSTRUCTION METHODS}

The top of the plastic drum were marked with the diameter approximately equal to the PVC pipe and was perforated and drilled using a hand drilling machine and round file was used to file the holes until the PVC pipe tightly fitted into the holes, four holes were differently measured and marked on top of the drum, they are thermometer, substrate inlet and overflow opening, gas outlet opening. A pipe measuring $60 \mathrm{~cm}$ in height was inserted at the substrate inlet and overflow opening from the top. This is the point for inlet and overflow of slurry. A measured hole with the PVC pipe was also drilled on the bottom of the drum, this serve as the outlet of sludge. The pipes were tightly fitted in the holes of the drum with aid of braces, PVC glue and four minute glue, which aided in appropriate sealant of the joints to avoid escape of gases that will be generated during the fermentation in the bioreactor. A pipe with gas tap was inserted into the gas outlet opening, which was connected to the manifold tester to trap the gas and measure its pressure while transferring the gas into the collator and finally, thermometer was inserted into its opening (5) 


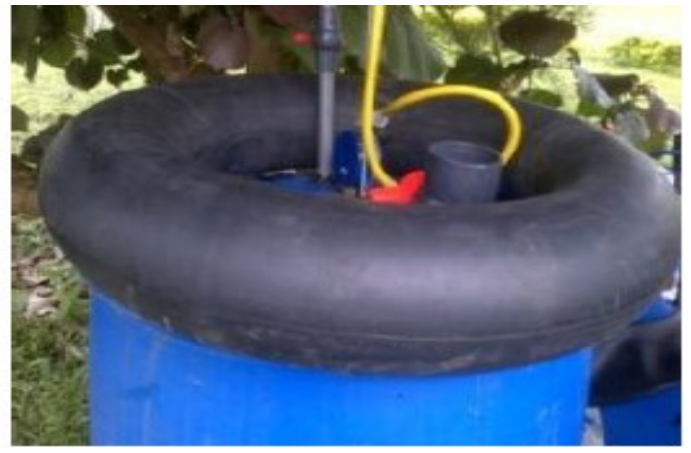

Figure 1: Biogas Generated from Chicken Waste

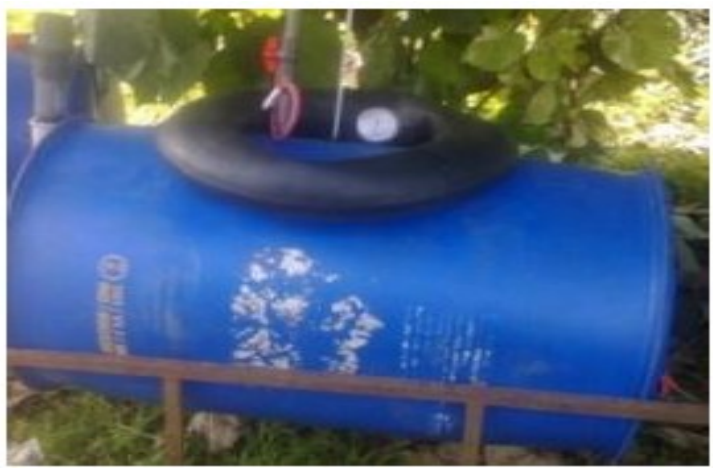

Figure 2: Biogas Generated from Cow Dung

\subsection{Source of Waste Use}

The cow dung used in this work was obtained from Abattoir Dump Site from Ndibe Beach, Afikpo, Ebonyi State, Nigeria while the kitchen wastes (vegetable lefts over, plantain peels and left over garri and rice was obtained from different eatery centers in Akanu Ibiam Federal Polytechnic, Unwana, Ebonyi State).

\subsection{Preparation and Measurement of Waste}

Fifty kilogram of cow dung were sun dried for 20 days while the kitchen wastes were milled into a coarse form followed by sun drying for 20 days. The slurry was prepared by measuring 50 liters $\left(0.05 \mathrm{~m}^{3}\right)$ of cow dung and poured into a pretreatment drum. One hundred liters $\left(0.1 \mathrm{~m}^{3}\right)$ of water was added to the cow dung inside the pre-treatment drum (i.e. in ratio 1:2, cow dung to water). The same procedure was applied to kitchen waste and stirred manually.

Finally, the slurry was transferred to the bioreactor for digestion process. The bioreactor was stirred at intervals. The thermometer at the top of the bioreactor measures the temperature. The temperature was weekly observed and recorded while the ambient temperature was also observed and recorded. Daily records of the biogas generated were also observed for twenty eight days. A GC Hp 68900 with HP Chemstation Rev A 0901 (1206) software was used to analyze the biogas generated by determining the constituents and percentage of each gas contained in the biogas generated and daily biogas generation was recorded.
Table 1: Average Daily Temperature in the Bioreactor and Ambient Per Day for the First Week

\begin{tabular}{|c|c|c|c|}
\hline & \multicolumn{3}{|c|}{ Average Daily Temperature } \\
\hline Time/Day & Kitchen Waste & Cow Dung & Ambient \\
\hline 1 & 32.556 & 32.555 & 29.564 \\
\hline 2 & 32.200 & 31.327 & 28.833 \\
\hline 3 & 31.667 & 31.473 & 27.957 \\
\hline 4 & 33.000 & 33.988 & 27.073 \\
\hline 5 & 32.302 & 32.147 & 28.147 \\
\hline 6 & 33.573 & 33.763 & 29.625 \\
\hline 7 & 30.268 & 30.231 & 30.321 \\
\hline Average & 32.224 & 32.212 & 28.789 \\
\hline
\end{tabular}

Table 2: Average Daily Temperature in the Bioreactor and Ambient Per Day for the Second Week

\begin{tabular}{|c|c|c|c|}
\hline & \multicolumn{3}{|c|}{ Average Daily Temperature } \\
\hline Time/Day & Kitchen Waste & Cow Dung & Ambient \\
\hline 1 & 32.926 & 32.589 & 29.264 \\
\hline 2 & 32.538 & 31.327 & 29.133 \\
\hline 3 & 31.473 & 31.269 & 28.217 \\
\hline 4 & 32.153 & 32.987 & 27.675 \\
\hline 5 & 32.302 & 32.214 & 27.974 \\
\hline 6 & 32.854 & 32.879 & 28.425 \\
\hline 7 & 31.684 & 31.239 & 28.421 \\
\hline Average & 32.276 & 32.072 & 28.444 \\
\hline
\end{tabular}

Table 3: Average Daily Temperature in the Bioreactor and Ambient Per Day for the Third Week

\begin{tabular}{|c|c|c|c|}
\hline & \multicolumn{3}{|c|}{ Average Daily Temperature } \\
\hline Time/Day & Kitchen Waste & Cow Dung & Ambient \\
\hline 1 & 31.546 & 31.452 & 28.884 \\
\hline 2 & 31.221 & 30.983 & 28.563 \\
\hline 3 & 30.637 & 31.273 & 27.857 \\
\hline 4 & 30.256 & 31.423 & 28.072 \\
\hline 5 & 31.102 & 31.127 & 28.267 \\
\hline 6 & 30.873 & 30.663 & 29.127 \\
\hline 7 & 30.542 & 30.331 & 29.512 \\
\hline Average & 30.882 & 31.036 & 28.612 \\
\hline
\end{tabular}


Table 4: Average Daily Temperature in the Bioreactor and Ambient Per Day for the Fourth Week

\begin{tabular}{|c|c|c|c|}
\hline & \multicolumn{3}{|c|}{ Average Daily Temperature } \\
\hline Time/Day & Kitchen Waste & Cow Dung & Ambient \\
\hline 1 & 30.436 & 30.654 & 29.326 \\
\hline 2 & 30.321 & 31.132 & 28.798 \\
\hline 3 & 30.397 & 30.273 & 28.534 \\
\hline 4 & 30.126 & 30.938 & 28.077 \\
\hline 5 & 29,978 & 30.128 & 28.523 \\
\hline 6 & 30.261 & 30.163 & 28.625 \\
\hline 7 & 29.148 & 30.281 & 29.331 \\
\hline Average & 30.095 & 30.509 & 28.744 \\
\hline
\end{tabular}

Table 5: Result of Biogas Analysis of Cow Dung and Kitchen Waste using Gas Chromatography

\begin{tabular}{|c|c|c|c|c|c|c|}
\hline & \multicolumn{6}{|c|}{ Biogas Component (\%) } \\
\hline Waste & $\mathrm{CH}_{4}$ & $\mathrm{NH}_{3}$ & $\mathrm{CO}$ & $\mathrm{H}_{2} \mathrm{~S}$ & $\mathrm{CO}_{2}$ & $\begin{array}{c}\mathrm{T} \\
\mathrm{al}\end{array}$ \\
\hline Kitchen Waste & 70.29 & 0.58 & 1.62 & 0.75 & $\begin{array}{c}26.7 \\
6\end{array}$ & 100 \\
\hline Cow Dung & 68.26 & 0.49 & 1.18 & 0.15 & $\begin{array}{c}29.9 \\
2\end{array}$ & 100 \\
\hline
\end{tabular}

Table 6: Daily Volume of Biogas Generated

\begin{tabular}{|c|c|c|c|c|}
\hline Waste & \multicolumn{2}{|c|}{ Cow Dung $\left(\mathrm{cm}^{3}\right)$} & \multicolumn{2}{|c|}{ Kitchen Waste } \\
\hline $\begin{array}{l}\text { No. of } \\
\text { Day }\end{array}$ & $\begin{array}{c}\text { Daily } \\
\text { Volume of } \\
\text { Gas }\end{array}$ & $\begin{array}{c}\text { Cumulative } \\
\text { Volume of } \\
\text { Gas }\end{array}$ & $\begin{array}{l}\text { Daily Volume } \\
\text { of Gas }\end{array}$ & $\begin{array}{c}\text { Cumulative } \\
\text { Volume of } \\
\text { Gas }\end{array}$ \\
\hline 1 & 0.0 & 0.0 & 0.0 & 0.0 \\
\hline 2 & 0.0 & 0.0 & 0.0 & 0.0 \\
\hline 3 & 5.6 & 5.6 & 6.4 & 6.4 \\
\hline 4 & 7.4 & 13.0 & 7.2 & 13.6 \\
\hline 5 & 7.9 & 20.9 & 7.7 & 21.3 \\
\hline 6 & 8.1 & 29.0 & 8.1 & 29.4 \\
\hline 7 & 8.0 & 37.0 & 8.4 & 37.8 \\
\hline 8 & 8.4 & 45.4 & 8.7 & 46.5 \\
\hline 9 & 8.9 & 54.3 & 8.9 & 55.4 \\
\hline 10 & 9.2 & 63.5 & 9.6 & 65.0 \\
\hline 11 & 9.8 & 73.3 & 9.7 & 74.7 \\
\hline 12 & 9.9 & 83.2 & 9.9 & 84.6 \\
\hline 13 & 10.2 & 93.4 & 10.6 & 95.2 \\
\hline 14 & 10.3 & 103.7 & 10.4 & 105.6 \\
\hline 15 & 9.6 & 113.3 & 10.0 & 115.6 \\
\hline 16 & 8.4 & 121.7 & 9.7 & 125.3 \\
\hline 17 & 6.2 & 127.9 & 9.2 & 134.5 \\
\hline 18 & 6.0 & 133.9 & 9.7 & 144.2 \\
\hline 19 & 5.8 & 139.7 & 8.3 & 152.5 \\
\hline 20 & 5.4 & 145.1 & 7.6 & 160.1 \\
\hline
\end{tabular}

\begin{tabular}{|l|l|l|l|l|}
\hline 21 & 4.6 & 149.7 & 7.1 & 167.2 \\
\hline 22 & 4.4 & 154.1 & 6.2 & 173.4 \\
\hline 23 & 3.6 & 157.7 & 5.8 & 179.2 \\
\hline 24 & 3.2 & 160.9 & 4.6 & 183.8 \\
\hline 25 & 2.4 & 163.3 & 3.1 & 186.9 \\
\hline 26 & 2.1 & 165.4 & 3.6 & 190.5 \\
\hline 27 & 2.0 & 167.4 & 2.2 & 192.7 \\
\hline 28 & 1.6 & 169 & 2.9 & 195.6 \\
\hline
\end{tabular}

\section{DISCUSSION}

The result of this research reveals that the generation biogas was not immediate; it was delayed for the first 24 hours. This can be traced to the fact that most cows feed on fibrous materials and the kitchen waste also contains fibrous materials. This is in conformity with the findings of (6), the absence of biogas generation in the first three days could be as a result of multiple carbon sources in the cow dung as one carbon source is exhausted due to the change to anaerobic condition, the microbial cells divert their source of energy for growth to a new carbon supply, (7). There was a gradual generation of biogas from the third day of fermentation. This suggests that the biogas generating microorganisms are in the lag phase of growth where adaptation of cells takes place. Daily volume of biogas generated showed that the third day, cumulative volume of biogas for cow dung was $5.6 \mathrm{~cm}^{3}$ to the 28th day $169.0 \mathrm{~cm}^{3}$ whereas, that of kitchen waste had the third day of cumulative biogas generate to be $6.4 \mathrm{~cm}^{3}$ and the 28 th day had $195.6 \mathrm{~cm}^{3}$. The temperature of the bioreactor was observed weekly, it was show the first two week had a little different in temperature than the last third and fourth week. The biogas analysis using chematography revealed that the component of methane was high in kitchen waste $70.29 \%$ and cow dung had $68.26 \%$. This is in line with the work of (8), and (9) that biogas, product of anaerobic digestion process mainly contain methane (up to $60 \%$ ) and low quantities of other gases.

\section{CONCLUSION}

In this research work, bioreactors were constructed to generate biogas and biofertilizer. The daily temperature and ambient of the substrates were recorded and their graph were plotted against time. The biogas generated by each bioreactor was taken for a gas chromatography analysis, it was observed that methane, carbon (II) oxide, hydrogen sulphide, ammonia were part of the component of the biogas. The daily biogas generation and its cumulative were also recorded.

\section{REFERENCES}

[1]. Thokchom,S,S, and Sankarlal,P. (2015): Production of biogas from kitchen waste using cow manue as co-substrate; Proceeding of the conference on energy conversion and conserwation

[2]. Adeyosoye, O.C., Adesokan, L.A., Afolabi, K.D. and Ekeocha, A.H. (2010). Estimation of Proximate Composition and Biogas Production from in vitro Gas Fermentation of Sweet Potatoes and 
Wild Cocoyam Peels. African Journal of Environmental Science and Technology, 4(6): $388-391$.

[3]. Monnet, F. (2003). An Introduction to Anaerobic Digestion of Organic Waste, being a Final Report submitted to Renade, Scotland available on http://www.ramadic.org.uk/media on introduction to anaerobic digestion. November 2003. Pdf $(30 / 05 / 2011$

[4]. Mshandete, A.M. and Parawira, W. (2009). Biogas Technology Research in Selected Sub-Saharan Africa. African Journal of Biotechnology, 8 (2): 116 - 125.

[5]. Atilade,A.O.,Onanuga,O.K, and Coker,J.O, (2014):Comparative study of biogas generation from chicken waste,cow dung and pig waste using constructed plastic biodigester
[6]. Ukpai, P. A. and Nnabuchi, M.N. (2012). Comparative Study of Biogas Production from Cow Dung, Cow Pea and Cassava Peeling using 45 litres Biogas Digester. Advances in Applied Science Research, 3 (3): 1864 - 1869.

[7]. Abubakar, B.S.U.I. and Ismail, N. (2012). Anaerobic Digestion of Cow Dung for Biogas Production ARPN. Journal of Engineering and Applied Sciences, 7 (2): 169 - 172.

[8]. McKendry, P. (2002). Energy Production from Biomass. Conversion Technologies Bioresources Technology, 83: 47 - 54.

[9]. Hiremath, R.B.K., Balachandra, P., Ravindramath, N.H. and Raghunandan, B.N. (2009). Decentralized renewable energy. Scope Relevance and Application in the Indian Context. Energy Sustainable Development, 13: 4- 10. 